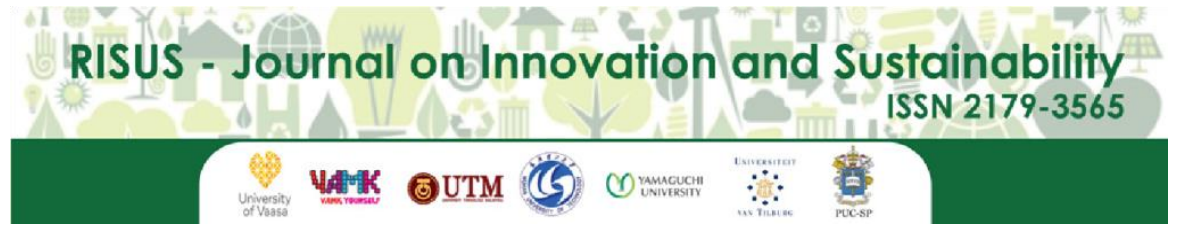

RISUS - Journal on Innovation and Sustainability volume 11, número1 - 2020 ISSN: $2179-3565$

Editor Científico: Arnoldo José de Hoyos Guevara Editor Assistente: Rosa Rizzi Avaliação: Melhores práticas editoriais da ANPAD

\title{
DISPARITIES IN OPEN DATA EFFORTS AMONG JAPANESE LOCAL GOVERNMENTS
}

Disparidades nos esforços de dados abertos entre os governos locais japoneses

\author{
Hideto Nakamura ${ }^{1}$, Yoko Ishino ${ }^{2}$ \\ 1 Graduate School of Sciences and Technology for Innovation, Yamaguchi University, \\ Yamaguchi, Japan, 7558611 \\ 2 Graduate School of Innovation \&Technology Management, Yamaguchi University, \\ Yamaguchi, Japan, 7558611 \\ E-mail:w006wc@yamaguchi-u.ac.jp, ishino.y@yamaguchi-u.ac.jp
}

\begin{abstract}
Opendata efforts have now become a global movement, and Japan intends to keep up with this global trend. Measures concerning open data have been undertaken since the Open Government Data Strategy was adopted in July 2012. As a result, all 47 Japanese prefectures had developed Web pages for their own open data by March in 2018. However, only $18.3 \%$ of municipalities had their open data released on the Internet. In this paper, we investigate how deeply opendata efforts have penetrated into local municipalities, not just the national average in Japan. By analyzing the opendata disparities, we then infer the factors that have facilitated opendata initiatives in local governments. We introduce an opendata penetration ratel for each prefecture, calculating it by using the number of municipalities that have already published their own open data, and we find that there is a regional disparity in the opendata efforts. By adding qualitative information to this quantitative research, we have found that there are three types of collaborations among the local governments that have already published open data. On the basis of these findings, we discuss which type of collaboration is the most promising for small-sized municipalities.
\end{abstract}

Keywords: Open data. Local government. Municipality. Regional revitalization

\author{
ACEITO EM: 15/01/2020 \\ PUBLICADO: $30 / 05 / 2020$
}




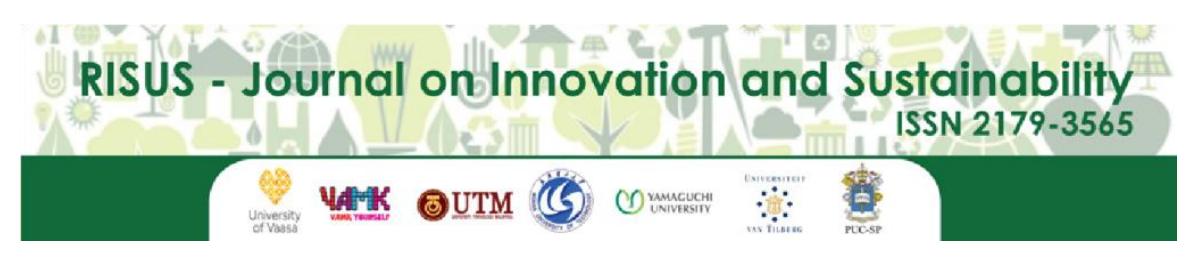

RISUS - Journal on Innovation and Sustainability volume 11, número 1 - 2020 ISSN: 2179-3565

Editor Científico: Arnoldo José de Hoyos Guevara Editor Assistente: Rosa Rizzi Avaliação: Melhores práticas editoriais da ANPAD

\title{
DISPARIDADES NOS ESFORÇOS DE DADOS ABERTOS ENTRE OS GOVERNOS LOCAIS JAPONESES
}

\author{
Disparities in Open Data Efforts among Japanese Local Governments
}

\begin{abstract}
Hideto Nakamura $^{1}$, Yoko Ishino ${ }^{2}$
1 Graduate School of Sciences and Technology for Innovation, Yamaguchi University, Yamaguchi, Japan, 7558611 2 Graduate School of Innovation \&Technology Management, Yamaguchi University, Yamaguchi, Japan, 7558611 E-mail:w006wc@yamaguchi-u.ac.jp, ishino.y@yamaguchi-u.ac.jp
\end{abstract}

\section{RESUMO}

Os esforços de Opendata tornaram-se um movimento global e o Japão pretende acompanhar essa tendência global. As medidas relativas aos dados abertos foram adotadas desde que a Estratégia de Dados do Governo Aberto foi adotada em julho de 2012. Como resultado, todas as 47 prefeituras japonesas desenvolveram páginas da Web para seus próprios dados abertos até março de 2018. No entanto, apenas 18,3\% dos municípios tiveram seus dados abertos divulgados na Internet. Neste artigo, investigamos como os esforços dos opendata penetraram profundamente nos municípios locais, não apenas na média nacional no Japão. Ao analisar as disparidades de opendata, inferimos então os fatores que facilitaram as iniciativas de opendata nos governos locais. Introduzimos uma taxa de penetração de opendata "para cada prefeitura, calculando-a usando o número de municípios que já publicaram seus próprios dados abertos, e descobrimos que há uma disparidade regional nos esforços dos opendata. Ao adicionar informações qualitativas a esta pesquisa quantitativa, descobrimos que existem três tipos de colaborações entre os governos locais que já publicaram dados abertos. Com base nessas descobertas, discutimos qual o tipo de colaboração mais promissor para os municípios de pequeno porte.

Palavras-chave: Dados abertos; Governo local; Município; Revitalização regional 


\section{INTRODUCTION}

Open data is that which is freely available for everyone to use and republish as they wish, without restrictions imposed by copyrights, patents, or other mechanisms of control (Auer, S., et al., 2007). Officially, open data is defined as public- or private-sector data held by the national government, local governments, or companies and that is published in a form to which all of the following apply: (1) The data are published under a rule allowing secondary use, whether or not for commercial purposes; (2) the data are published in a machinereadable format; and (3) the data can be used free of charge(Basic Principles on Open Data, 2017).

Opendata efforts are a global movement that was initially led by the US and UK governments, but which is rapidly spreading to many countries in Europe, Asia, and also the Americas (Takagi, S., 2014). In 2013, the Open Data Charter was agreed to by the leaders of the countries at the G8 Summit, with the aim of proactively addressing open data in the participating countries (G8 Open Data Charter, 2013).

Naturally, Japan has followed this trend. Measures concerning open data have been undertaken in Japan since the Open Government Data Strategy was adopted in July 2012 (Japan Open Data Charter Action Plan, 2013). This strategy outlined the significance and objectives of promoting the use of public data, as itemized below (Open Government Data Strategy, 2012).

- Enhance Transparency and Confidence

- Promote Public Participation and Collaboration between the Public and Private Sectors

- Economic Stimulus and Higher Efficiency in Government

Today, Japan has many problems, such as a declining birth rate and an aging population, the concentration of the population in large cities, and the sluggishness of the economy. Especially in local areas, these problems are critical, and the revitalization of such regions is an urgent matter. Opendata initiatives may be of some help for such problems.

Various positive effects are expected for Open Government Data. Making government information available to the public as machine-readable open data can facilitate government transparency and lead to increased government accountability. Also, open data can support technological innovation and economic growth by enabling third parties or private companies to develop new kinds of digital products and services. A trivial example is that statistical data released by the government can be used to determine regional differences, which may lead to the development of more effective strategies for some products or services.

The aforementioned -Open Government Data Strategyll states that both the national government and local governments are expected to drive opendata efforts forward. In reality, however, opendata efforts have progressed mainly because of the initiative of the national government, and we question how deeply these efforts have penetrated into local municipalities.

This research therefore aims to clarify the opendata initiative ratio for each prefecture, rather than considering just the national average in Japan. By analyzing the open data disparities, we can then determine the factors that hamper or facilitate the opendata initiatives by local governments. These results can contribute to the development of a strategy to further the progress of such opendata efforts in the near future.

\section{DATA AND METHODOLOGY}

The website of IT Strategic Headquarters, -Government CIOs' Portal, Japanll contains many kinds of decision documents and statistical data on the current government-wide open data initiatives of the Japanese government (Government CIOs' Portal, Japan). This site also contains not only the national government's data concerning opendata efforts but also local municipalities' data. It includes a - list of open data sites by local governments\| that is periodically updated by IT Strategic Headquarters. We took advantage of these municipalrelated data, published on April 30, 2018, for our research purposes. 
First, based on the list of municipalities on this site, we calculated an -open-data penetration ratell for each prefecture. Since the area of a prefecture includes the cities or towns in it, we obtained the penetration rate by dividing the number of cities or towns that have already published their own open data by the total number of cities or towns existing in that individual prefecture. Based on the ranking of the penetration rates soobtained, we then selected advanced local governments and scrutinized those governments' opendata efforts to determine the factors that have facilitated their opendata initiatives. Finally, we investigated duplications between a prefecture's Web site and a municipality's Web site, as well as those among different municipalities' Web sites. We did this to determine the effects of joint operations on a local government's opendata site.

\section{RESULTS AND DISCUSSIONS}

\subsection{Open data penetration rate by prefecture}

All 47 Japanese prefectures had Web pages for their own open data by March 2018, according to the government's Web page (Government CIOs' Portal, Japan)(Kashihara, H.,2018). We assume that this occurred because the national government put pressure on the prefectures to follow the opendata movement. On the other hand, only 319 municipalities had their open data released on the Internet, although there were 1741 municipalities in total. In short, the opendata penetration rate for municipalities was only $18.3 \%$ on average.

Apart from the national average value, we were interested in regional gaps among opendata efforts. Since a prefecture contains many municipalities, we decided to compare the penetration rates of the opendata initiatives among prefectures. In this paper, we define the opendata penetration rate for a prefecture as the ratio of the number of municipalities with their own open data on the Internet to the number of all municipalities existing in the prefecture. Based on the list on the government's Web page (Government CIOs' Portal, Japan), we calculated the opendata penetration rate for each prefecture, as shown in Table 1. The geographical distribution of penetration rates for all 47 prefectures is shown in Figure 1.

Table 1 Open Data Penetration Rates by Prefecture

$\begin{array}{cccc}\text { Ranking } & \text { Prefecture } & \begin{array}{c}\text { \# of Contained } \\ \text { Municipalities }\end{array} & \begin{array}{c}\text { \#Open Data } \\ \text { Penetration Rate }\end{array} \\ 1 & \text { Fukui } & 17 & 94.1 \% \\ 2 & \text { Shizuoka } & 35 & 77.1 \% \\ 3 & \text { Kanagawa } & 33 & 66.7 \% \\ 4 & \text { Okayama } & 27 & 48.1 \% \\ 5 & \text { Saitama } & 63 & 44.4 \% \\ 6 & \text { Ishikawa } & 19 & 42.1 \% \\ 7 & \text { Aichi } & 54 & 40.7 \% \\ 8 & \text { Tokyo } & 62 & 38.7 \% \\ 9 & \text { Tokushima } & 24 & 37.5 \% \\ 10 & \text { Toyama } & 15 & 33.3 \% \\ 11 & \text { Tochigi } & 25 & 32.0 \% \\ 12 & \text { Yamaguchi } & 19 & 26.3 \% \\ 13 & \text { Niigata } & 30 & 23.3 \% \\ 14 & \text { Chiba } & 54 & 22.2 \% \\ 15 & \text { Hyogo } & 41 & 22.0 \% \\ 16 & \text { Hiroshima } & 23 & 21.7 \% \\ 17 & \text { Shiga } & 19 & 21.1 \% \\ 18 & \text { Osaka } & 43 & 20.9 \% \\ 19 & \text { Mie } & 29 & 20.7 \% \\ 20 & \text { Kagawa } & 17 & 17.6 \% \\ 21 & \text { Nara } & 39 & 15.4 \% \\ 22 & \text { Miyazaki } & 26 & 15.4 \%\end{array}$




$\begin{array}{lccc}23 & \text { Ehime } & 20 & 15.0 \% \\ 24 & \text { Saga } & 20 & 15.0 \% \\ 25 & \text { Fukuoka } & 60 & 11.7 \% \\ 26 & \text { Shimane } & 19 & 10.5 \% \\ 27 & \text { Fukushima } & 59 & 10.2 \% \\ 28 & \text { Aomori } & 40 & 10.0 \% \\ 29 & \text { Gifu } & 42 & 9.5 \% \\ 30 & \text { Nagano } & 77 & 9.1 \% \\ 31 & \text { Miyagi } & 35 & 8.6 \% \\ 32 & \text { Akita } & 25 & 8.0 \% \\ 33 & \text { Kyoto } & 26 & 7.7 \% \\ 34 & \text { Ibaraki } & 44 & 6.8 \% \\ 35 & \text { Wakayama } & 30 & 6.7 \% \\ 36 & \text { Oita } & 18 & 5.6 \% \\ 37 & \text { Tottori } & 19 & 5.3 \% \\ 38 & \text { Okinawa } & 41 & 4.9 \% \\ 39 & \text { Nagasaki } & 21 & 4.8 \% \\ 40 & \text { Kumamoto } & 45 & 4.4 \% \\ 41 & \text { Hokkaido } & 179 & 3.9 \% \\ 42 & \text { Yamanashi } & 27 & 3.7 \% \\ 43 & \text { Iwate } & 33 & 3.0 \% \\ 44 & \text { Yamagata } & 35 & 2.9 \% \\ 45 & \text { Gumma } & 35 & 2.9 \% \\ 46 & \text { Kagoshima } & 43 & 2.3 \% \\ 47 & \text { Kochi } & 34 & 0.0 \%\end{array}$

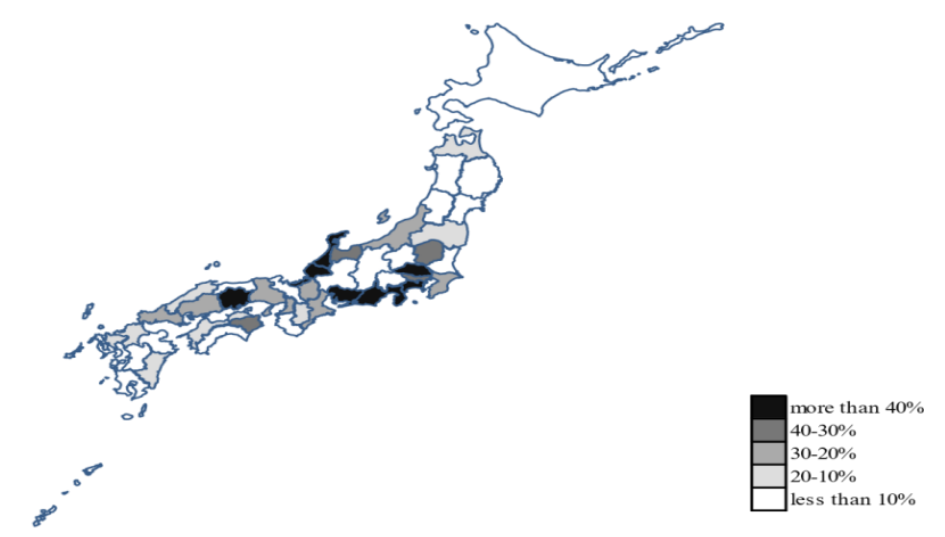

Figure 1 Geographical Distribution of Prefectures' OpenData Penetration Rates

As shown in Table 1, the highest and lowest values were recorded by Fukui $(94.1 \%)$ and Kochi $(0 \%)$, respectively. We found that there is no correlation between a prefecture's opendata penetration rate and the number of municipalities existing in the prefecture; Pearson's correlation coefficient between the two is -0.143 . In addition, there were no specific regional biases regarding the prefecture's penetration rate, according to Figure 1. Then, the frequency distribution of penetration rates for all 47 prefectures is shown in Figure 2.As indicated in Figure 2, the opendata penetration rates for most prefectures turned out to be less than 50\%. 


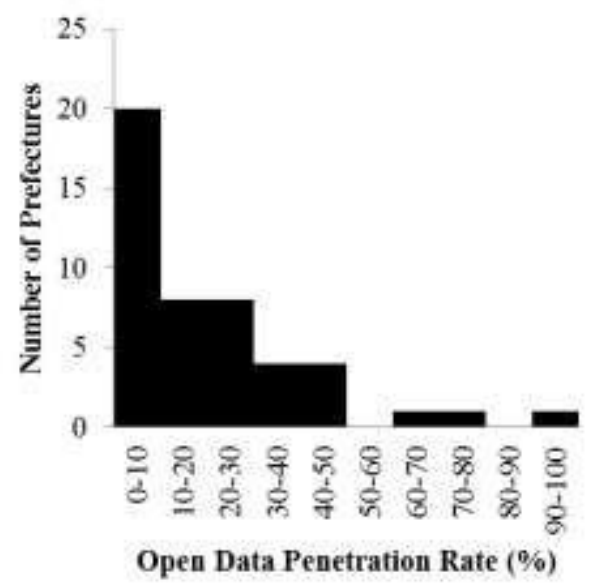

Figure 2 Histogram of Prefectures' OpenData Penetration Rates

We then wondered if the penetration rate might be affected by the fiscal size (revenue), population, or population density of a prefecture. We therefore calculated correlation and partial-correlation matrices between these variables (Tables 2 and 3). As shown in Tables 2 and 3, out of these three variables, the opendata penetration rate had the strongest correlation with population size, although the correlation coefficient was only 0.33. Figure 3 is a scatter plot showing the relationship between the open-data penetration rate and the populations of the prefectures, where each dot represents an individual prefecture. Figure 3 suggests that there is only a weak relationship between these two variables.

To determine what the important factors that have facilitated prefectures' opendata efforts are, we focused on the top five prefectures: Fukui, Shizuoka, Kanagawa, Okayama, and Saitama, and we then investigated qualitatively how each had performed its opendata initiative. We examined the Web sites of these prefectures and reviewed the interview logs that we had previously conducted with the person in charge of the opendata initiatives in each of these prefectures.

Table 2 Correlation Matrix between Variables

\begin{tabular}{l|cccc}
\hline & Revenue & Population & $\begin{array}{c}\text { Population } \\
\text { Density }\end{array}$ & $\begin{array}{c}\text { Open Data } \\
\text { penetration } \\
\text { Rate }\end{array}$ \\
\hline Revenue & 1.000 & 0.889 & 0.838 & 0.182 \\
Population & & 1.000 & 0.894 & 0.331 \\
Population Density & & & & \\
Open Data penetration Rate & & & & \\
\end{tabular}

Table 3 Partial-Correlation Matrix between Variables

\begin{tabular}{l|rrrc}
\hline & Revenue & Population & $\begin{array}{c}\text { Population } \\
\text { Density }\end{array}$ & $\begin{array}{c}\text { Open Data } \\
\text { penetration } \\
\text { Rate }\end{array}$ \\
\hline Revenue & 1.000 & 0.602 & 0.230 & - \\
Population & & 1.000 & 0.546 & 0.275 \\
Population Density & & & & 0.256 \\
Open Data penetration Rate & & & & \\
& & & & \\
\end{tabular}




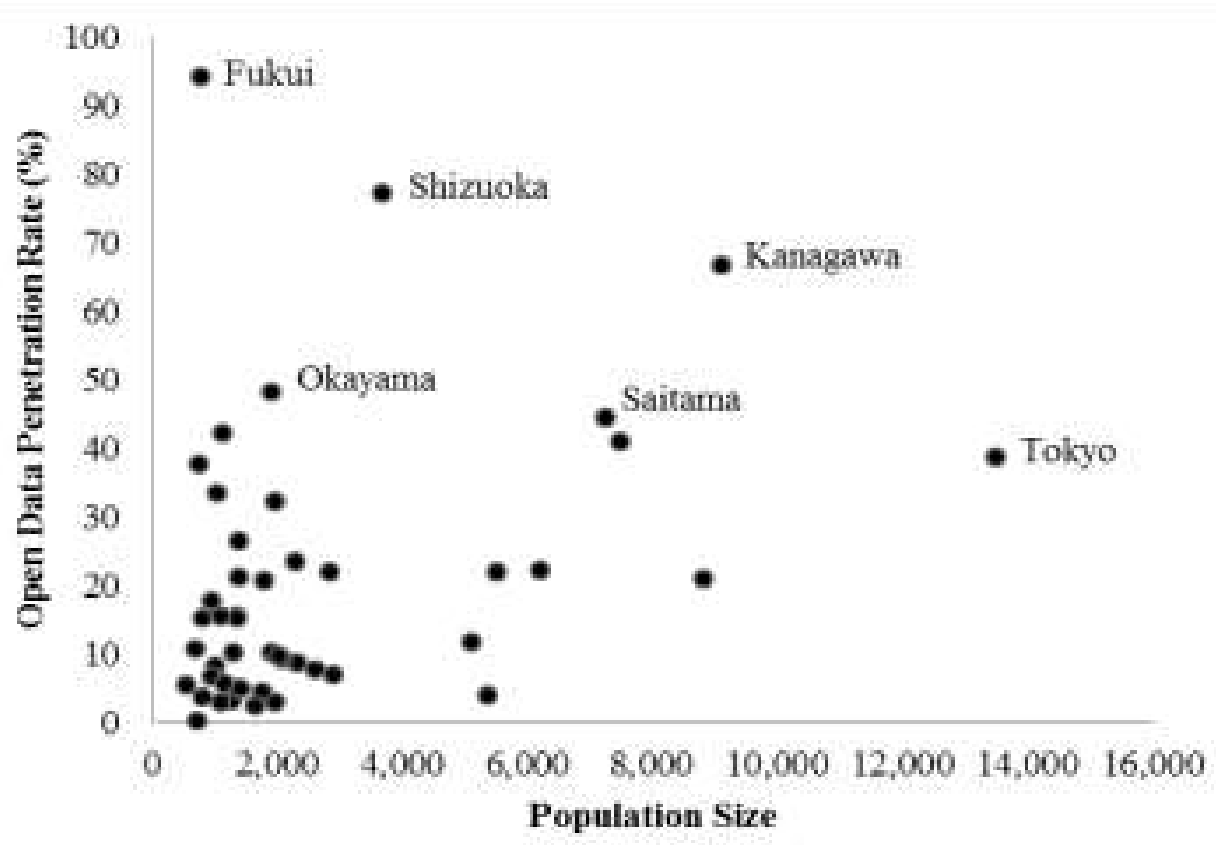

Figure 3 ScatterPlot of Prefectures' OpenData Penetration Ratevs. Population

\subsection{Details of the top five prefectures' opendata efforts}

We examined the opendata sites on the Internet for the top five prefectures-Fukui, Shizuoka, Kanagawa, Okayama, and Saitama - in June 2018, and we also performed a literature survey of their opendata efforts. In addition, we reviewed in detail the logs of interviews that we had conducted in 2015 with the person in charge of the opendata initiatives in each of these prefectures. The main results were as follows:

(1)Fukui Prefecture

There were various types of information on this prefecture's open-data site. Typical examples were the following, which were released as -Open data jointly published by Fukui Prefecture and all 17 municipalities existing in Fukui: (1)A list of evacuation sites for all municipalities, (2) information about public facilities possessed by Fukui Prefecture and/or by the municipalities, (3) a list of garbage-collection dates for all municipalities, and (4) guidelines for trash separation in each municipality. Fukui includes Sabae City, which has been quite advanced in its opendata efforts; in January 2012, Sabae City became the first to publish its open data (Seto, T., et al., 2015).

Generally speaking, open data may differ in machine readability, depending upon the file format. Tim Berners-Lee, who is an inventor of the Web and Linked Data, has proposed a -5-star deployment scheme $\|$ as a guide to machine readability, as shown in Figure 4. It has been widely used all over the world for judging how well opendata initiatives have progressed (Shadbolt, N., et al., 2012). 


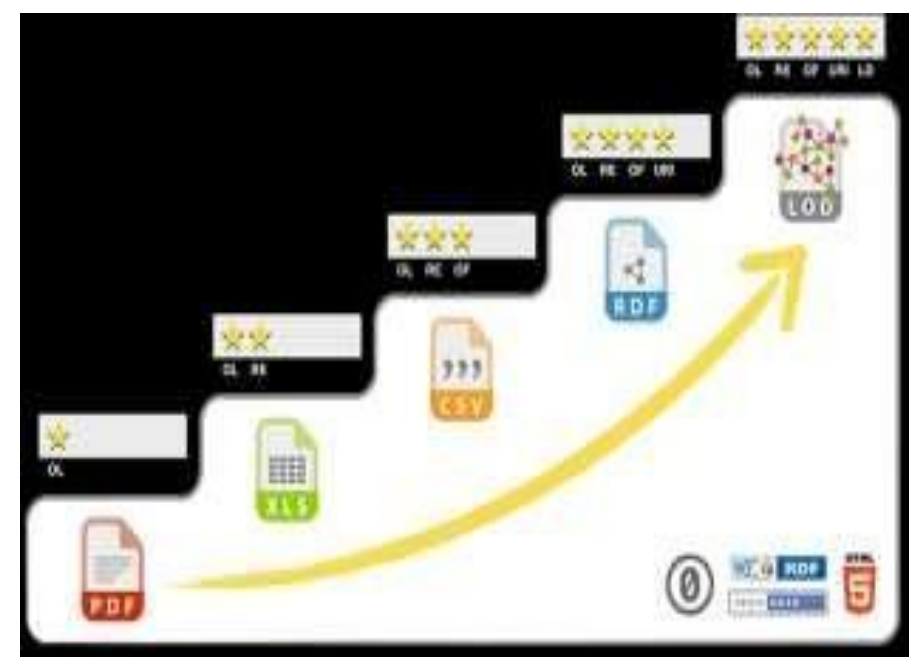

Figure 4 5-Star Deployment Scheme

From: http://5stardata.info/en/

Fukui Prefecture's opendata sites contained various files in from CSV format (3-star rating) to LinkedRDF format (5-star rating). Because most prefectures provide open data in formats of 4 stars or less, Fukui Prefecture has been highly rated by the authorities.

According to the interview we conducted in 2015, Fukui Prefecture had allocated a dedicated staff member in the information system division to drive forward this effort. He was trained to handle open data and to promote uniformity in the datatypes of files to be uploaded.

(2)Shizuoka Prefecture

The opendata sites managed by Shizuoka Prefecture contained open data for most of the municipalities it contains. A few municipalities in this prefecture-like Mishima City-published open data in the 5-star rating file format. In August 2013, Shizuoka Prefecture published the -Open Data Catalog Shizuoka as the first prefectural opendata portal site in Japan (White Paper 2014, 2015).

Through the interview we conducted in 2015, we found that two staff members belonging to the information system department had been assigned in charge of overseeing an open data system. Those members started to develop the open data system without outsourcing by using open-source software (OSS). This is a type of computer software for which the source code is released under a license in which the copyright holder grants users the rights to study, change, and distribute the software to anyone and for any purpose. Those staff members had tackled the opendata issue from their own perspective alone. Because of such in-house software development, there were pros and cons to this approach. An advantage is that the developers can flexibly modify the system, as they want. In contrast, a disadvantage is that the performance of the system depends greatly on the ability of a limited number of developers, and no one else can operate the system without them.

(3)Kanagawa Prefecture

Kanagawa Prefecture consolidated the following data for all 33 municipalities it contains and published them on the prefecture's opendata site. The data included (1) information about the locations and services of libraries and children's halls, (2) information on the locations of parks and play equipment, and (3) information about evacuation sites for all municipalities and locations of automated external defibrillators.

(4)Okayama Prefecture

Like Shizuoka Prefecture, the opendata sites managed by Okayama Prefecture contained open data for many of the municipalities it contains. Municipalities in Okayama Prefecture seemed to be able to publish their own data using the upload function on the Okayama portal site. The data-upload system had been built using 
$\mathrm{CKAN}^{1}$, which is a type of OSS. Apart from the main opendata site, seven cities and three towns jointly run a site named — data eye: data portal of the watershed areas of Takahashi-gawa River.

(5)Saitama Prefecture

Like Shizuoka Prefecture, the opendata sites managed by Saitama Prefecture contained open data for most of the municipalities it contains. Municipalities in SaitamaPrefecture also seemed to be able to publish their own data using the upload function on the Saitama portal site. The data-upload system had been built using CKAN, like Okayama Prefecture. Some kinds of data for Saitama Prefecture were published in a 5-starrating file format.

\subsection{System sharing for publishing open data}

From the details of the top five prefectures' opendata efforts, we found that several prefectures had organized a collaborative opendata project with their municipalities. This collaboration seemed very important in facilitating the opendata initiatives. We therefore investigated the duplication between a prefecture's Web site and a municipality's Web site and also those among the different municipalities' Web sites. We browsed duplicate sites and inquired into the situation directly.

Eventually, we found that there are three types of collaborations between local governments for publishing open data, which are expressed in Web-site duplication or in the sharing of a site's function. These include (1) a type of collaboration in which a prefecture compiles data to be opened from its municipalities and the prefecture uploads them; (2) a type of collaboration in which a prefecture provides to its municipalities an opendata release function on a portal site, and the municipalities then use this function themselves; and (3) a type of collaboration in which several neighboring municipalities collaborate together to build a common opendata release site. In this paper, these three types of collaborations are called Types A, B, and C, respectively. We investigated which types of collaborations were used in an individual prefecture, and the results are presented in Table 4.

Table 4 System Sharing Situation for Publishing Open Data

\begin{tabular}{|c|c|c|c|c|c|c|c|c|c|}
\hline $\begin{array}{c}\text { Ranking of } \\
\text { ODPR }\end{array}$ & Prefecture & Type A & Type B & $\begin{array}{l}\text { Type } \\
\text { C }\end{array}$ & $\begin{array}{l}\text { Ranking of } \\
\text { ODPR }\end{array}$ & Prefecture & Type A & Type B & $\begin{array}{l}\text { Type } \\
\text { C }\end{array}$ \\
\hline 1 & Fukui & $\checkmark$ & & & 25 & Fukuoka & & & $\checkmark$ \\
\hline 2 & Shizuoka & & $\checkmark$ & & 26 & Shimane & & & \\
\hline 3 & Kanagawa & $\checkmark$ & & & 27 & Fukushima & $\checkmark$ & & \\
\hline 4 & Okayama & & $\checkmark$ & $\checkmark$ & 28 & Aomori & & & \\
\hline 5 & Saitama & & $\checkmark$ & & 29 & Gifu & & & \\
\hline 6 & Ishikawa & & & & 30 & Nagano & & & \\
\hline 7 & Aichi & & & & 31 & Miyagi & & & \\
\hline 8 & Tokyo & & & & 32 & Akita & & & \\
\hline 9 & Tokushima & & $\checkmark$ & & 33 & Kyoto & & & \\
\hline 10 & Toyama & & & & 34 & Ibaraki & & & \\
\hline
\end{tabular}

${ }^{1}$ CKAN: https://ckan.org/ 


\begin{tabular}{|c|c|c|c|c|}
\hline 11 & Tochigi & $\checkmark$ & 35 & Wakayama \\
\hline 12 & Yamaguchi & & 36 & Oita \\
\hline 13 & Niigata & & 37 & Tottori \\
\hline 14 & Chiba & & 38 & Okinawa \\
\hline 15 & Hyogo & & 39 & Nagasaki \\
\hline 16 & Hiroshima & & 40 & Kumamoto \\
\hline 17 & Shiga & & 41 & Hokkaido \\
\hline 18 & Osaka & & 42 & Yamanashi \\
\hline 19 & Mie & & 43 & Iwate \\
\hline 20 & Kagawa & & 44 & Yamagata \\
\hline 21 & Nara & & 45 & Gumma \\
\hline 22 & Miyazaki & $\checkmark$ & 46 & Kagoshima \\
\hline 23 & Ehime & & 47 & Kochi \\
\hline 24 & Saga & & & \\
\hline
\end{tabular}

Collaborations of Type A were used in Fukui, Kanagawa, and Fukushima. Type A has the problem that it forces a large administrative burden on an individual in the prefecture who then takes responsibility for publishing the data. In the case of Fukui Prefecture, a full-time staff member was assigned to the section for such a job. However, it is likely to be difficult for other municipalities to do the same thing as Fukui Prefecture, since cost reductions and personnel reductions have recently been required in most municipalities.

Type B was used in Shizuoka, Okayama, Saitama, Tokushima, and Miyazaki. As described above, Shizuoka, Okayama, and Saitama used OSS for incorporating the opendata release function on a portal site. The advantages of using OSS not only increase the flexibility of the system design but also decrease the system-development costs. In particular, CKAN, which was adopted by Okayama Prefecture and Saitama Prefecture, is customized for publishing open data, with a unique feature that enables tagging. By using this feature, CKAN easily deals with tagged open data. For example, if a different tag is set for the data from each different municipality, these tagged data are easily handled in a prefecture's portal site without confusion. Since the cost of OSS such as CKAN is inexpensive, a small-scale municipality would benefit from using this approach.

Type C was used in Okayama, Tochigi, and Fukuoka. Unlike Types A and B, Type C is a collaboration in which several municipalities cooperate to construct a common opendata release site. Since a prefecture which has wide-ranging influence on its many municipalities - does not take part in the cooperation, it is necessary for one or another municipality to take the role of a core municipality, demonstrating leadership and coordinating ability, to facilitate the collaborative work.

In summary, judging both from the number of prefectures that have already implemented each type of collaboration and from the opendata content that has already been published, Type B seems to be the most promising approach for collaboration among local governments. 
A partir dos artigos analisados, percebemos alguns consensos na literatura sobre mensuração e avaliação das iniciativas de Gestão de Pessoas. É notório que estas ações devem estar ligadas à estratégia da empresa e devem fornecer um feedback efetivo sobre o resultado dos investimentos feitos na área.

No entanto, o que encontrado foi uma escassa produção acadêmica sobre o assunto, muito espaçada ao longo dos anos e baseada em sua totalidade em artigos e autores internacionais.

Esta situação ocorre, em parte, pela dificuldade das empresas em implantar estes projetos e da consequente impossibilidade da academia em estuda-los.

As limitações deste estudo se deve à pouca literatura disponível prejudicando um estudo bibliográfico. Outra limitação vem do fato da pesquisa centrar-se apenas em periódicos nacionais, ficando aqui a sugestão de um próximo estudo em âmbito mundial.

Outra oportunidade para estudo seria a aplicação de um levantamento incluindo pequenas e médias empresas no escopo da pesquisa, uma vez que em nenhum dos quatro artigos estudados tais empresas fizeram parte do foco do estudo.

\section{CONCLUSION}

In this paper, we found that opendata efforts have progressed in some municipalities in Japan, although the efforts have not yet been introduced sufficiently in many other municipalities. We calculated the opendata penetration rate for each prefecture by using the number of municipalities that had already published their own open data, and we found that there is a regional disparity in the opendata efforts. By adding qualitative information to this quantitative research, we found that there are three types of collaborations among local governments that facilitate the publishing of open data. Type A is a collaboration type in which a prefecture compiles data to be opened from its constituent municipalities and the prefecture uploads them. In Type B, a prefecture provides an opendata release function on a portal site to its constituent municipalities, and they upload open data by themselves using this function. In Type $\mathrm{C}$, several neighboring municipalities collaborate to build a common opendata release site. Out of these three types, Type B seems to be the most promising way for local governments to collaborate.

Third parties or private companies may develop new kinds of digital products and/or services if it is possible to invent new uses by combining different kinds of open data. This is potentially capable of leading to technological innovation and economic growth.

In the future, we plan to conduct additional interviews with key persons in charge of the opendata efforts in municipalities. In addition, we intend to conduct research to find out how open data can contribute to regional revitalization.

\section{REFERENCES}

AAUER, S., Bizer, C., Kobilarov, G., Lehmann, J., Cyganiak, R., Ives, Z. DBpedia: A Nucleus for a Web of Open Data [C]. In: Aberer K. et al. (eds) The Semantic Web. ISWC 2007, ASWC 2007. Springer, Berlin, Heidelberg, 2007,722-735.

Basic Principles on Open Data [R]. Approved by the IT Strategic Headquarters and Strategic Committee for the Advancement of Utilizing Public and Private Sector Data, 2017.

TAKAGI, Soichiro. Research note: an introduction to the economic analysis of open data [J]. The Review of Socionetwork Strategies, 2014,8 (2):119-128.

G8 Open Data Charter [R]. 2013. 
Japan Open Data Charter Action Plan [R]. Adopted by the Ministry CIO Liaison Committee, 2013.

Open Government Data Strategy [R].Adopted by the IT Strategic Headquarters, 2012.

KASHIHARA, Hiroshi. Special topic: Open data rolling out in Japan: 47 prefectures and 303 municipalities already implemented it [R]. Nikkei glocal, Nikkei Publishing Inc., 2018, 338:8-17 (In Japanese)

SETO, Toshikazu, Sekimoto, Yoshihide. Comparing the Distribution of Open Geospatial Information between the Cities of Japan and Other Countries [C]. CUPUM (Computers in Urban Planning and Urban Management) 2015 conference papers, 2015,14:1-14

SHADBOLT, N., O'Hara, K., Berners-Lee, T., Gibbins, N., Glaser, H., Hall, W. Linked Open Government Data: Lessons from Data.gov.uk [J]. Intelligent Systems, 2012,27(3):16-24

White Paper 2014 on Information and Communications in Japan, Ministry of Internal Affairs and Communications, Japan [R]. 2015. 